\title{
PGPR Isolates from the Rhizosphere of Vegetable Crop Momordica charantia: Characterization and Application as Biofertilizer
}

\author{
Ritu Singh*, Kapil D. Pandey, Ajay Kumar and Monika Singh \\ Centre of Advance Study in Botany, Banaras Hindu University, Varanasi- 221 005, India \\ *Corresponding author
}

\author{
A B S T R A C T
}

\begin{tabular}{|c|}
\hline Keywords \\
\hline $\begin{array}{l}\text { Bitter melon, } \\
\text { plant growth } \\
\text { promoting } \\
\text { rhizobacteria } \\
\text { (PGPR), PGP } \\
\text { traits, biofertilizer. }\end{array}$ \\
\hline Article Info \\
\hline $\begin{array}{l}\text { Accepted: } \\
\text { 24 February } 2017 \\
\text { Available Online: } \\
\text { 10 March } 2017\end{array}$ \\
\hline
\end{tabular}

Plant growth promoting Rhizobacteria (PGPR) enhance the plant growth and productivity through wide variety of mechanism. The strains isolated from rhizosphere of Momordica charantia, mainly belonged to Bacillus, Azotobacter, Pseudomonas and Acinetobacter. Nearly 50\% isolates of Pseudomonas and Acinetobacter and all the isolates of Bacillus and Azotobacter were able to solubilise tricalcium phosphate. All the isolates were positive for Catalase activity and IAA production except Acinetobacter with $75 \%$ isolates were IAA producing. Pseudomonas (100\%), Bacillus (80\%), Acinetobacter (75\%) and Azotobacter (40\%) produced ammonia and all the isolates were siderophore producing except Azotobacter. The Bacillus (75\%) and Pseudomonas (50\%) also produce HCN. Best performers in above plant growth promotion (PGP) traits, isolate of Bacillus (R7), Azotobacter (RS7), Pseudomonas (RS1) and Acinetobacter (R12) evaluated for their effect on plant vigour. The antibacterial activity and plant growth promotion in Pseudomonas (RS1), salt tolerance in Bacillus (R7), and nitrogenase activity $\left(\mathrm{C}_{2} \mathrm{H}_{2}\right.$-reduction) in Azotobacter (RS7) was highest. Pseudomonas (RS1) was most efficient PGPR and Bacillus (R7) most dominant in rhizosphere of bitter melon. Nitrogenase $\left(\mathrm{C}_{2} \mathrm{H}_{2}-\right.$ reduction), phosphate solubilisation and growth promotion activities in Bacillus (R7), Azotobacter (RS7) and Pseudomonas (RS1) suggested that these isolates may be used as a biofertilizer for bitter melon.

\section{Introduction}

Plant Growth Promoting Rhizobacteria (PGPR) are a group of naturally occurring soil bacteria that aggressively colonize plant roots and increase plant growth and yield (Wu et al., 2005). They prevent the colonization of deleterious rhizospheric microorganisms (DRMOs) at micro-niches and can promote plant growth directly or indirectly. It is interesting to study the diverse bacterial taxa for their PGPR characteristics (Lucy et al., 2004). The numbers of PGPR species has increased due to studies on a wide range of plant species, advancement in bacterial taxonomy and progress in understanding the different mechanisms of action of PGPR. The increased number of PGPR for various crops and vegetables has been commercialize as a biofertilizer, recently includes Pseudomonas (Loper et al., 2007), Azospirillum (Cassán and García Salamone, 2008), Bacillus (Jacobson et al., 2004), Stenotrophomonas (Ryan et al., 2009), Rhizobium (Long, 2001), Serratia (De Vleeschauwer and Höfte, 2007), Azotobacter, Klebsiella, Enterobacter, Alcaligens, Arthrobacter, Burkholderia (Joseph et al., 2007) and Streptomyces (Schrey and Tarkka., 
2008). Pseudomonas and Bacillus are the most commonly investigated PGPR and often dominate the rhizosphere (Morgan et al., 2005).

The mode of action of PGPR involves complex mechanisms to promote plant growth, development and protection. As bioprotectant, they suppress the plant diseases through induction of systemic resistance and production of antibiotics and siderophore. PGPR promotes plant growth by improving nutrient acquisition, as a biofertilizer and by producing phytohormones such as indole acetic acid, gibberellic acid, cytokinin and ethylene (Glick, 1995) as a biostimulant. Some PGPR may promote plant growth indirectly by stimulating symbiotic $\mathrm{N}_{2-}$ fixation, nodulation and nodule occupancy (Joseph et al., 2007) and by asymbiotic $\mathrm{N}_{2-}$ fixation (Boddey and Dobereiner, 1995). In addition to above traits, the plant growth promoting strain must be rhizospheric competent, able to survive and colonize in the rhizospheric soil (Cattelan et al., 1999). Unfortunately, the interaction between associative PGPR and plants can be unstable and the good results obtained in vitro (Zhender et al., 1999). The variability in the performance of PGPR may be due to various environmental factors that affect the plants growth, includes climate, weather conditions, soil characteristics or the composition and activity of the indigenous microflora of the soil (Joseph et al., 2007). Inoculation of ornamentals, horticultural and forest trees nurseries, vegetable and agricultural crop seedlings, seeds or soil with PGPR may result in multiple effect on plant growth, such as enhancement of seed germination, seedling growth, seedling health, plant vigor, plant height, shoot weight, nutrient content of shoot tissues, early bloom, chlorophyll content and increased nodulation in legumes (Saharan, 2011).
Isolating native strains adapted to the local environment has always been successful to the formulation of PGPR inoculants to use in vegetables crops. Our interest is to isolate and screen some well known PGPR strains of Bacillus, Pseudomonas, Azotobacter and Acinetobacter from rhizosphere of nutritionally and pharmaceutically important vegetable crop, Momordica charantia (bitter melon) and also to evaluate plant growth promotion potentials of the above PGPR on bitter melon plants.

\section{Materials and Methods}

\section{Site}

The study conducted in earthen pot filled with amended natural soil kept in Botanical garden, Banaras Hindu University $\left(20^{\circ} 18^{\prime} \mathrm{N}\right.$ and $83^{\circ} 36^{\prime} \mathrm{E}$, elevation $80.71 \mathrm{~m}$ ).

\section{Plants and soil sampling}

Momordica charantia Linn. (Bitter melon), seeds were sown in natural soil added with manure and sand $(2: 1: 1)$ in earthen pots and seedlings appears within 10- 15 days after sowing (DAS). At flowering stage (45 DAS), rhizospheric soil was collected by gentle shaking the entire root system to remove loosely adhering soil. Physicochemical analysis of soil collected from bitter melon pots at the flowering stage was performed and brief description of methods was as given below:

Total soil organic carbon, Total N, Available $N, P$ and $K$ determined by method described by (Jackson, 1967).

Soil microbial biomass $C$ and $N$ were estimated by direct chloroform fumigation and extraction method as described by (Vance et al., 1987). 
Soil $p H$ was measured in the soil solution (1:2; soil: water, w/v) using the combined glass electrode $\mathrm{pH}$ meter. 2.2.4 Soil Moisture Content was determined based on fresh weight and soil dried to constant weight at $80^{\circ} \mathrm{C}$

\section{Isolation of Plant Growth Promoting Bacteria}

Rhizospheric soil (fresh weight) was suspended in $50 \mathrm{ml}$ buffer solution (phosphate buffer $10 \mathrm{mM}, \mathrm{pH}-7.0$ ), shaken vigorously $1 \mathrm{~h}$ on a gravatory shaker and serially diluted up to $10^{-5}$. Bacterial strains isolated by plating the soil dilution on agar plate; Bacillus and Acinetobacter were isolated on LB nutrient agar plates (Carlton and Brown, 1981), Azotobacter on Jensen's agar plates (Norris and Chapman,1968) and Pseudomonas on King's B agar plates ( King, 1954). The plates were incubated at $30^{\circ} \mathrm{C}$ for $2-7$ days. The bacterial colonies were chosen based on colony morphology and visual growth rates. Clones picked up and purified by streaking on the respective plates. Colonies were restreaked on fresh nutrient agar plates for isolation and maintenance of isolates.

Pure isolates of PGPR from rhizospheric soil was characterized by using the criteria described in Bergey's Manual of Systematic Bacteriology (Bergey's Manual of Determinative Bacteriology $9^{\text {th }}$, 1994) and Bergey's Manual of Determinative Bacteriology (Bergey's Manual of Determinative Bacteriology, 1984). The PGPR strain was identified on the basis of colony behaviour, morphological and biochemical characteristics.

\section{Morphological Characterization of PGPR}

Colony morphology of each isolate was examined on LB agar plates. After 3 day of incubation, different characteristics of colonies such as shape, size, elevation, surface, margin, colour, optical characteristics, pigmentation, recorded.

A phenotypic characteristic of bacterial cell of each isolates were examined by preparing a smear of diluted a loopful of bacterial culture on slide and fixed by heating on a flame. The slide was flooded with crystal violet solution for $3 \mathrm{~min}$, washed gently in flow of tap water and air-dried. The slide was observed under microscope and recorded the shape.

The smear prepared as above flooded with crystal violet solution (1 min), washed gently in flow of tap water and then flooded with iodine solution, for $1 \mathrm{~min}$. Iodine complex was drained out followed by washing with $95 \%$ ethanol. The smear incubated with safranin solution for $1 \mathrm{~min}$. Then, the slide observed under microscope and Gram-reaction recorded.

Motility of bacteria was determined by hanging drop method. A drop of loopful 2day-old bacteria in $1 \mathrm{ml}$ of nigrosin solution took on a cover slip that hanged on a hollow slide with Vaseline. The slide was then observed under microscope to test motility of bacteria.

\section{Biochemical characterization of PGPR}

Isolates of Bacillus (15), Pseudomonas (2), Azotobacter (5) and Acinetobacter (4) were biochemically characterized by Oxidase test, $\mathrm{H}_{2} \mathrm{~S}$ production, Citrate test, Urease test, Carbohydrates production, Starch hydrolysis and Nitrate reduction by the following method.

Oxidase Test- The loop full culture from single colony was just touched on the Standard Oxidase disc and immediate development of blue colour considered as positive. 
Hydrogen Sulphide Test- SIM medium with lead acetate as indicator used for testing the ability of strains to produce $\mathrm{H}_{2} \mathrm{~S}$.

Citrate Test- Simmon's Citrate medium green in colour, if the inoculated bacteria utilize citrate the $\mathrm{pH}$ increases gradually and medium becomes blue in alkaline $\mathrm{pH}$.

Urease Test- Few drop of indicator phenol red added to the medium, a colour change from yellow to bright pinkish-red is positive; lack of colour change is a negative result for urease.

Nitrate Reduction- Addition of three drops of each solution A (Sulphanilic acid) and solution B (dimethyl-alpha-naphthyalmine) to two days old culture of an isolate in nitrate broth and appearance of pink colour considered as positive to nitrate reduction ability.

Carbohydrates fermentation Test- An isolate grown in Hugh- Leifson's test medium containing bromothymol blue at $37{ }^{\circ} \mathrm{C}$ for 24 hours to 4 days. Development of yellow colour due to change in colour of indicator, shows acid production from carbohydrate fermentation.

Starch hydrolysis Test- Few drops of Gram's iodine solution were added to the two days old culture of an isolate grown on starch agar plate. The dark blue colour developed due to formation of starch iodine complex. Clear area around streaked culture indicates the degradation of starch due to production of amylase.

\section{Characterization of Plant growth promoting bacteria for PGP traits}

Phosphate solubilisation: A loopful $(20 \mu \mathrm{l})$ of each bacterial isolate was placed on the centre of modified Pikovskaya agar plate containing insoluble tricalcium phosphate (TCP) and incubated at $30 \pm 0.1^{\circ} \mathrm{C}$ for 5 days. The formation of clear zone indicated the phosphate solubilising potential of bacteria (Gupta et al., 1994).

Quantitative estimation of phosphate: The Phosphate solubilisation activity of the selected PGPR isolates was estimated as per methodology described by authors [Nautiyal and Mehta, 2001; Jackson, 1973). Bacterial isolates grown in National Botanical Research Institute's Phosphate (NBRIP) broth containing $0.5 \%$ tricalcium phosphate. The flask containing $100 \mathrm{ml}$ medium inoculated with $1 \mathrm{ml} 48 \mathrm{~h}$ old bacterial culture in triplicate and incubated at $28^{\circ} \mathrm{C}$ for 7 days on a shaker at $180 \mathrm{rpm}$. Simultaneously, under similar conditions the uninoculated control also kept. The test cultures centrifuged at $10,000 \mathrm{rpm}$ for $10 \mathrm{~min}$. To a $0.5 \mathrm{ml}$ aliquot of the supernatant, $2.5 \mathrm{ml}$ Barton's reagent added and made the volume to $50 \mathrm{ml}$ with deionized water. The absorbance of the resultant colour read after $10 \mathrm{~min}$ at $430 \mathrm{~nm}$ in UV/Visible Spectrophotometer. The total soluble phosphorus calculated from the regression equation of standard curve prepared from $\mathrm{K}_{2} \mathrm{HPO}_{4}$. The values of soluble phosphate liberated expressed as $\mu \mathrm{g}$ ml-1 over control.

Ammonia production: Bacterial isolates were tested for the production of ammonia in peptone water. Freshly grown cultures were inoculated in $10 \mathrm{ml}$ peptone water and incubated for 48 to $78 \mathrm{~h}$ at $36 \pm 2{ }^{\circ} \mathrm{C}$. Nessler's reagent $(0.5 \mathrm{ml})$ was added in each tube. Development of brown to yellow colour was a positive test for ammonia production (Cappuccino and Sherman, 1992)

Detection of indole acetic acid production: IAA production was detected by the modified method described by Brick et al., 1991. Quantitative analysis of IAA was performed 
using the method (Loper and Scroth, 1986) at $50 \mu \mathrm{g} / \mathrm{ml}$ concentrations of tryptophan. Bacterial cultures were grown for $48 \mathrm{~h}$ in LB Broth medium at $28 \pm 2{ }^{\circ} \mathrm{C}$. Bacterial cultures were centrifuged at $3000 \mathrm{rpm}$ for $30 \mathrm{~min}$. The supernatant $(2 \mathrm{ml})$ was mixed with two drops of orthophosphoric acid and $4 \mathrm{ml}$ of the Salkowski reagent $(50 \mathrm{ml}, 35 \%$ of perchloric acid, $\quad 1 \mathrm{ml} \quad 0.5 \mathrm{M} \quad \mathrm{FeCl}_{3} \quad$ solution). Development of pink colour indicates IAA production. Absorbance was read at $535 \mathrm{~nm}$ with the help of UV/ Visible spectrophotometer. Concentration of IAA produced by cultures was measured with the help of standard graph of IAA (Hi-media) obtained in the range of $10-100 \mu \mathrm{g} / \mathrm{ml}$.

Hydrogen cyanide production: Screening of bacterial isolates for hydrogen cyanide (HCN) production was done by adapted method (Castric, 1975). Bacterial cultures were streaked on nutrient agar medium containing $4.4 \mathrm{~g}$ per litre of glycine. A Whatman filter paper no. 1 soaked in $0.5 \%$ picric acid solution (in $0.2 \%$ sodium carbonate) was placed inside the lid of a plate. Plates were sealed with paraffin and incubated at $30 \pm 0.1^{\circ} \mathrm{C}$ for 4 days. Development of light brown to dark brown colour indicated HCN production.

Catalase activity: Immediate gas bubbles formation was considered Catalase positive when single colony was mixed 2-3 drops of $3 \% \mathrm{H}_{2} \mathrm{O}_{2}$ on clean grease free glass slide.

Siderophore production: Bacterial strains grown on blue agar plates containing the dye chromazurol $\mathrm{S}$ (CAS), the formation of orange halos around the colonies were indicative for siderophore production (Schwyn and Neilands, 1987)

$\mathrm{N}_{2}$-fixation $\left(\mathrm{C}_{2} \mathrm{H}_{2}\right.$-reduction) assay: The Nitrogenase activity $\left(\mathrm{C}_{2} \mathrm{H}_{2}\right.$ - reduction assay) (Schollhorn and Burris, 1967) was performed in $10 \mathrm{ml}$ vacuotainer tubes containing $2.5 \mathrm{ml}$ of the medium. Isolates grown in Burk's N- free medium $\left(48 \mathrm{~h}\right.$ at $\left.30^{\circ} \mathrm{C}\right)$ were transferred $(1 \mathrm{ml})$ to each vial sealed with airtight rubber stopper and the headspace was injected with $10 \%(\mathrm{v} / \mathrm{v})$ acetylene after removing equal amount of air. Gas samples $(50 \mu \mathrm{l})$ removed after $1 \mathrm{~h}$ and assayed for ethylene production in a gas chromatograph equipped with Poropak-R column and a flame ionization detector (Varian, USA). Ethylene produced was determined using standard ethylene (Scott Specialty Gases, Deerfield IL 60015). Values expressed as nmol $\mathrm{m}^{-1} \mathrm{~h}^{-1}$.

Antimicrobial activity: The antimicrobial activity of selected isolates of PGPR strains was done by agar well diffusion method (Mehmood et al., 1999). The PGPR isolates tested for their antibacterial activity were grown in LB broth medium. Test bacteria such as human pathogenic strains of Escherichia coli and Pseudomonas aeruginosa were grown in LB broth medium. LB broth was taken as negative control and $30 \mu \mathrm{g} / \mathrm{ml}$ Chlorempenicol was used as positive control. After 5-6 days of incubation at $30^{\circ} \mathrm{C}$, the antibacterial activity was evaluated by measuring inhibition zone against test organisms.

\section{Salt stress}

The selected bacterial strains were tested for their tolerance to salt stress by inoculating them in LB broth medium containing various concentration of $\mathrm{NaCl}(1 \%$ to12\%) and $0.1 \mathrm{ml}$ of culture $\left(1.0 \times 10^{7}\right.$ cell ml $\left.{ }^{-1}\right)$ was inoculated in $10 \mathrm{ml} \mathrm{LB}$ broth. The culture tubes incubated at $30^{\circ} \mathrm{C}$ for 48 hours and analyzed for influence of salt by taking OD at $600 \mathrm{~nm}$ by UV/Visible spectrophotometer just after inoculation and after incubation for $24 \mathrm{~h}$.

\section{Experimental Design}

The effect of PGPR isolates Bacillus (R7), Azotobacter (RS7), Pseudomonas (RS10) and 
Acinetobacter (R12) on bitter melon was determined by conducting a pot experiment. The experiment was designed in five sets with three earthen pots in each set and soil from botanical garden added with manure and sand in proportion 2:1:1 ratio. Set 1 served as control without treatment of bacterium and in Set. 2, 3, 4 and 5, (one set for each PGPR strain) sterile soil seeded with three bitter melon seeds. Seeds were inoculated with Bacillus (R7), Azotobacter (RS7), Pseudomonas (RS10) or Acinetobacter (R12) culture $\left(10^{9}\right.$ cell ml $\left.{ }^{-1}\right)$ and pelleted with $\mathrm{CaCO}_{3}$ powder.

All five sets of pots kept under natural environment in botanical garden and watered on each alternate day. Different traits of plant were studied such as seed germination, seedling length, plant height, number of fruits per plant, fruits size and number of seeds per fruit.

\section{Results and Discussion}

The physicochemical characteristics of the rhizospheric soil such as soil organic carbon $(0.85 \%)$, total nitrogen $(0.085 \%)$, moisture content $(17.10 \%)$, soil $\mathrm{pH}(7.1)$ and other parameters were at a level, which could be favorable for the growth of PGPR(data not presented).

The Momordica charantia rhizosphere was associated with a diversity of bacterial population. Among the selected bacterial strains population (CFU per gram dry soil) Bacillus sps $\left(4.7 \times 10^{8}\right)$ was dominant in the rhizosphere followed by, Acinetobacter $(0.24$ $\left.\mathrm{x} 10^{8}\right)$, Pseudomonas sps $\left(0.1 \times 10^{8}\right)$, and Azotobacter sps $\left(0.51 \times 10^{7}\right)($ Fig- 1$)$. On the basis of cultural, morphological and biochemical characteristics out of total 42 soil isolates, 26 isolates grouped as Bacillus, Azotobacter, Pseudomonas and Acinetobacter. The cultural (3-4 days colony), morphological and biochemical characteristics of all the test isolates are given in Table 1.

All the 26 isolates of four bacterial genera were characterized for their PGP traits in vitro are depicted in Table 2. Catalase activity was detected by all the bacterial strains that may be potentially very advantageous. Only Bacillus and Pseudomonas exhibited HCN production. The IAA production, ammonia production and phosphate solubilisation activity was present in all the isolates of Bacillus, Azotobacter, Pseudomonas and Acinetobacter. Except Azotobacter, all the bacterial isolates produced siderophore.

We had selected four isolates, one each of Bacillus, Azotobacter, Pseudomonas and Acinetobacter based on high PGP activity and coded as R7, RS7, RS1 and R12, respectively. These isolates formed high phosphate solubilisation zone (16- $24 \mathrm{~mm}$ ) and liberated high quantity of soluble phosphate (210$\left.418 \mu \mathrm{g} \mathrm{ml}^{-1}\right)$. All the selected isolates such as Bacillus (R7), Azotobacter (RS7), Pseudomonas (RS1) and Acinetobacter (R12) produced IAA (ranges from $0.2-3.1 \mu \mathrm{g} \mathrm{ml}^{-1}$ ) at $50 \mu \mathrm{g}$ Tryptophan concentration. Except Acinetobacter (R12), Bacillus (R7), Azotobacter (RS7) and Pseudomonas (RS1) isolates exhibited high nitrogenase $\left(\mathrm{C}_{2} \mathrm{H}_{2-}\right.$ reduction) activity which was maximum in Azotobacter (RS7) (72 nmol. $\mathrm{C}_{2} \mathrm{H}_{4} \mathrm{ml}^{-1} \mathrm{~h}^{-1}$ ). All the three later strains also exhibited antibacterial activity against human pathogenic strains of $E$. Coli with inhibition zone (12 to $23 \mathrm{~mm}$ ) whereas only Bacillus (R7) and Pseudomonas (RS1) exhibited antibacterial activity against $P$. aeruginosa with inhibition zone of 25 and $11 \mathrm{~mm}$. Pseudomonas (RS1) has maximum $\mathrm{P}$ solubilisation $\left(418 \mu \mathrm{g} \mathrm{ml}^{-1}\right)$, IAA production (3.1 $\left.\mu \mathrm{g} \mathrm{ml}^{-1}\right)$ and antibacterial activities (23 $\mathrm{mm}$ in E. coli and $25 \mathrm{~mm}$ in $P$. aeruginosa) (Table 3). These strains further selected for 
the salinity tolerance and traits of growth promotion on bitter melon.

Among all the four selected strains of plant growth promoting Rhizobacteria, Bacillus (R7) tolerated high concentration of salt $(\mathrm{NaCl})$ and could survive at $12 \%$ salt conc. whereas complete death of Azotobacter (RS7), Pseudomonas (RS1) and Acinetobacter (R12) occurred at 11\%, $8 \%$ and $10 \%$ respectively (Fig. 2).

The effect of Bacillus (R7), Azotobacter (RS7), Pseudomonas (RS1) and Acinetobacter (R12) on bitter melon plant has been presented in Table 4. Azotobacter (RS7) and Pseudomonas (RS1) supported 100\% seed germination. Pseudomonas (RS1) treated seeds attained maximum seedling length $(12.67 \pm 0.9)$, plant height $(158.83 \pm 5.8)$, fruit number per plant $(18 \pm 1.7)$, fruit size $(12 \pm 0.6)$, and fruit has maximum number of seeds (16) followed by Bacillus (R7), Azotobacter (RS7) and least in Acinetobacter (R12).

PGPR are root colonising bacteria which exert beneficial effects on plant growth by production of phytohormones, $\mathrm{HCN}$, ammonia and antibiotics, suppression of deleterious organisms, activation of phosphate solubilisation, promotion of mineral uptake and aggressive colonization of micro niches (Maier et al., 2009). There are many papers related to the advantages and screening of PGP traits of PGPR from vegetable plants particularly tomato, potato, chilli, lettuce, cucumber but the studies performing isolation and characterization of selected genera of PGPR from bitter melon rhizosphere and its effect on plant growth and yield are extremely limited.

The bacterial rhizosphere community structure was soil-specific; bitter melon rhizosphere has all the physico-chemical property, which was strongly affected plant growth promoting bacterial population. Rhizospheric soils have high soil organic carbon, total nitrogen and available nitrogen, essential for both PGPR population and plant growth.

The dominance of Bacillus as a PGPR in the rhizospheric soil of bitter melon further confirmed that Bacillus sp is a successful PGPR and its beneficial role has already been established (Probanza et al., 2002). Phosphate solubilisation was most frequently detected in Bacillus and Azotobacter and to a lesser extent in Pseudomonas and Acinetobacter as evident by formation of phosphate solubilisation zone more than $11 \mathrm{~cm}$. The results of bitter melon supported the view of Reyes and Valduz (2006) who reported the dominance of phosphate solubilising bacteria in the rhizosphere as compared to nonrhizospheric soil.

IAA production is an important trait of PGPR because it is most important phytohormones and function as signal molecule in the regulation of plant development. The production of IAA by PGPR can vary among different species and strains, as observed during the present study, also influenced by culture condition, growth stage and substrate availability (Mirza et al., 2001). Other research workers (Xie et al., 2006) also recorded IAA production in Azotobacter isolates are in agreement with other authors (Gonzalez- Lopez et al., 1986) and high level of IAA production by Pseudomonas. Production of IAA and soluble phosphate are the most common mechanisms of actions implicated in PGPR and indeed microbes demonstrating the same are wide spread in rhizosphere (Vessey, 2003). Besides Phosphate solubilisation and IAA production, another important traits of PGPR that may indirectly influence the plant growth, is production of ammonia that is strain specific 
characteristics among the PGPR isolates. Siderophore production was common in PGPR isolates but not a rule, as Azotobacter isolates did not produce siderophore. PGPR strains producing siderophore competitively ensures its unavailability to the phytopathogens and thus contribute to disease suppression. Siderophore may directly stimulate the biosynthesis of other anti microbial compound by increasing the availability of minerals to bacteria. $\mathrm{HCN}$ production also plays an important role in the biological control of pathogens and act as PGP traits. Production of HCN by isolates of Bacillus and Pseudomonas are positive further confirmed that $\mathrm{HCN}$ production is a strain specific PGP traits and acts as an inducer of plant resistance (Joseph et al., 2007). All the bacterial isolates produce
Catalase and it has been postulated that strains showing Catalase activity must be highly resistant to environmental, mechanical and chemical stress (Joseph et al., 2007; Kumar et al., 2012). Nitrogen fixation is one of the major mechanisms utilized by PGPR for the plant growth promotion. The nitrogenase $\left(\mathrm{C}_{2} \mathrm{H}_{2}\right.$ - reduction) activity assay performed in all the four selected PGPR isolates of bitter melon detected the nitrogenase activity in Bacillus (R7), Azotobacter (RS7) and Pseudomonas (RS1) strains while Acinetobacter (R12) did not show the nitrogenase activity. A number of studies suggest that PGPR enhances the plant growth and contribute to the protection of plants against pathogens and pests (Dey et al., 2004).

Table.1 Culture (3-4 days colony), morphological and biochemical characteristics of PGPR isolates

\begin{tabular}{|c|c|c|c|c|}
\hline Characteristics & Bacillus & Azotobacter & Pseudomonas & Acinetobacter \\
\hline \multicolumn{5}{|l|}{ Culture Colony } \\
\hline Shape & Round & Round & Round & Round \\
\hline Size $(\mathrm{mm})$ & $1.5-2.0$ & $1.0-5.0$ & $2.0-3.0$ & Pin headed \\
\hline Elevation & Raised & Raised & Raised & Raised \\
\hline Surface & Rough & Slimy & Smooth & Smooth \\
\hline Margin & Serrated & Smooth & Smooth & Smooth \\
\hline Optical characteristics & Opaque & Opaque & Translucent & Opaque \\
\hline Colour & White & $\begin{array}{l}\text { Creamy beige } \\
\text { white }\end{array}$ & Light green & Light cream \\
\hline \multicolumn{5}{|l|}{ Morphology } \\
\hline Gram's reaction & $G+v e$ & $\mathrm{G}-\mathrm{ve}$ & G-ve & $\mathrm{G}-\mathrm{ve}$ \\
\hline Shape & Rod & Rod & rod & Rod \\
\hline Pigment & - & + & $+/-$ & - \\
\hline Motiliy & + & + & + & - \\
\hline \multicolumn{5}{|l|}{ Biochemical } \\
\hline Oxidase & + & + & + & - \\
\hline Citrate & + & + & + & + \\
\hline Indole & - & + & - & - \\
\hline $\mathrm{H}_{2} \mathrm{~S}$ Production & - & - & + & - \\
\hline Urease & - & + & + & - \\
\hline Carbohydrate fermentation & + & + & - & - \\
\hline Starch hydrolysis & + & + & + & + \\
\hline Nitrate Reduction & + & + & + & - \\
\hline
\end{tabular}


Table.2 Plant growth promoting characteristics of bacterial isolates

\begin{tabular}{llllllll}
\hline Bacterial isolates & $\begin{array}{l}\text { No. of } \\
\text { isolates }\end{array}$ & $\begin{array}{l}\mathbf{P} \\
\text { Solubiliz } \\
\text { ation }\end{array}$ & $\begin{array}{l}\text { IAA } \\
\text { product } \\
\text { ion }\end{array}$ & $\begin{array}{l}\text { Ammonia } \\
\text { production }\end{array}$ & $\begin{array}{l}\text { Siderophore } \\
\text { production }\end{array}$ & $\begin{array}{l}\text { HCN } \\
\text { production }\end{array}$ & $\begin{array}{l}\text { Catalase } \\
\text { activity }\end{array}$ \\
\hline Bacillus spp & 15 & + & + & + & + & + & + \\
& & $(100)$ & $(100)$ & $(80)$ & $(93.3)$ & $(73.3)$ & $(100)$ \\
Azotobacter spp & 5 & + & + & + & ND & ND & + \\
& & $(100)$ & $(100)$ & $(40)$ & & & $(100)$ \\
Pseudomonas spp & 2 & + & + & + & + & + & + \\
& & $(50)$ & $(100)$ & $(100)$ & $(50)$ & $(50)$ & $(100)$ \\
Acinetobacter spp & 4 & + & + & + & + & ND & + \\
& & $(50)$ & $(75)$ & $(75)$ & $(50)$ & & $(100)$ \\
\hline
\end{tabular}

Number in parenthesis shows percentage of isolates; += Positive; ND= Not detected

Table.3 Different Plant Growth Promoting activities of some selected bacterial isolates

\begin{tabular}{|c|c|c|c|c|c|c|c|}
\hline \multirow{2}{*}{$\begin{array}{l}\text { Isolates name } \\
\text { code }\end{array}$} & \multirow[t]{2}{*}{ with } & \multicolumn{2}{|c|}{ Phosphate solubilisation } & \multirow{2}{*}{$\begin{array}{l}\text { IAA } \\
\text { Production } \\
\left(\mu \mathrm{ml}^{-1}\right) \pm \mathrm{SE} \\
\text { at 50 } 5 \mathrm{~g} \\
\text { Tryptophan } \\
\text { conc. }\end{array}$} & \multirow{2}{*}{$\begin{array}{l}\mathrm{N}_{2^{-}} \text {fixation } \\
\left(\mathrm{C}_{2} \mathrm{H}_{2^{-}}\right. \\
\text {reduction; } \mathrm{n} \\
\mathrm{mol} \mathrm{C}_{2} \mathrm{H}_{4} \\
\left.\mathrm{ml}^{-1} \mathrm{~h}^{-1}\right)\end{array}$} & \multicolumn{2}{|c|}{ Antibacterial Activity } \\
\hline & & $\begin{array}{l}\text { Zone of } \\
\text { clearance } \\
(\text { diam. in } \\
\text { mm })^{*} \pm \mathrm{SE}\end{array}$ & $\begin{array}{l}\text { Concentration } \\
\left(\mu \mathrm{g} \mathrm{ml}^{-1}\right) \\
\pm \mathrm{SE}\end{array}$ & & & $\begin{array}{l}\text { Zone of Inl } \\
\text { SE) } \\
\text { Escherichia } \\
\text { coli }\end{array}$ & $\begin{array}{l}\text { ibition (mm } \pm \\
\text { Pseudomonas } \\
\text { aeruginosa }\end{array}$ \\
\hline \multirow{2}{*}{\multicolumn{2}{|c|}{$\begin{array}{l}\text { Bacillus sp. (R7) } \\
\text { Azotobacter sp. (RS7) }\end{array}$}} & $24 \pm 1.7$ & $372 \pm 1.2$ & $0.21 \pm 0.03$ & $47 \pm 2.3$ & $21 \pm 1.0$ & $11 \pm 0.4$ \\
\hline & & $18 \pm 1.7$ & $246 \pm 3.5$ & $1.6 \pm 0.01$ & $72 \pm 0.0$ & $12 \pm 0.4$ & ND \\
\hline $\begin{array}{l}\text { Pseudomonas } \\
\text { (RS1) }\end{array}$ & sp. & $29 \pm 2.5$ & $418 \pm 2.9$ & $3.1 \pm 0.3$ & $42 \pm 1.2$ & $23 \pm 0.9$ & $25 \pm 0.74$ \\
\hline $\begin{array}{l}\text { Acinetobacter } \\
\text { (R12) }\end{array}$ & sp. & $16 \pm 1.7$ & $210 \pm 1.5$ & $1.0 \pm 0.2$ & ND & ND & ND \\
\hline
\end{tabular}

$\mathrm{ml}^{-1}=$ Absorbance, 0.4 at $710 \mathrm{~nm} ; \mathrm{ND}=$ Not detected; $*=20 \mu 1$ inoculated on the plate

Fig.1 Population of bacterial species in rhizosphere soil by bitter melon

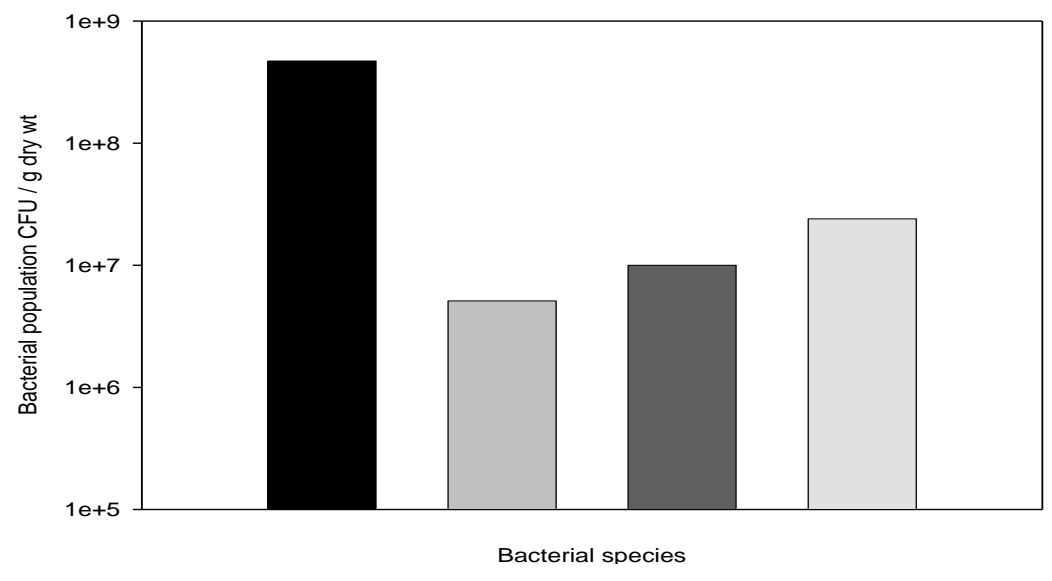

Bacillus sp Azotobacter sp - Pseudomonas $s p \quad$ Acinetobacter $s p$ 
Fig.2 Effect of salinity $(\mathrm{NaCl})$ on the growth of selected PGPR strains

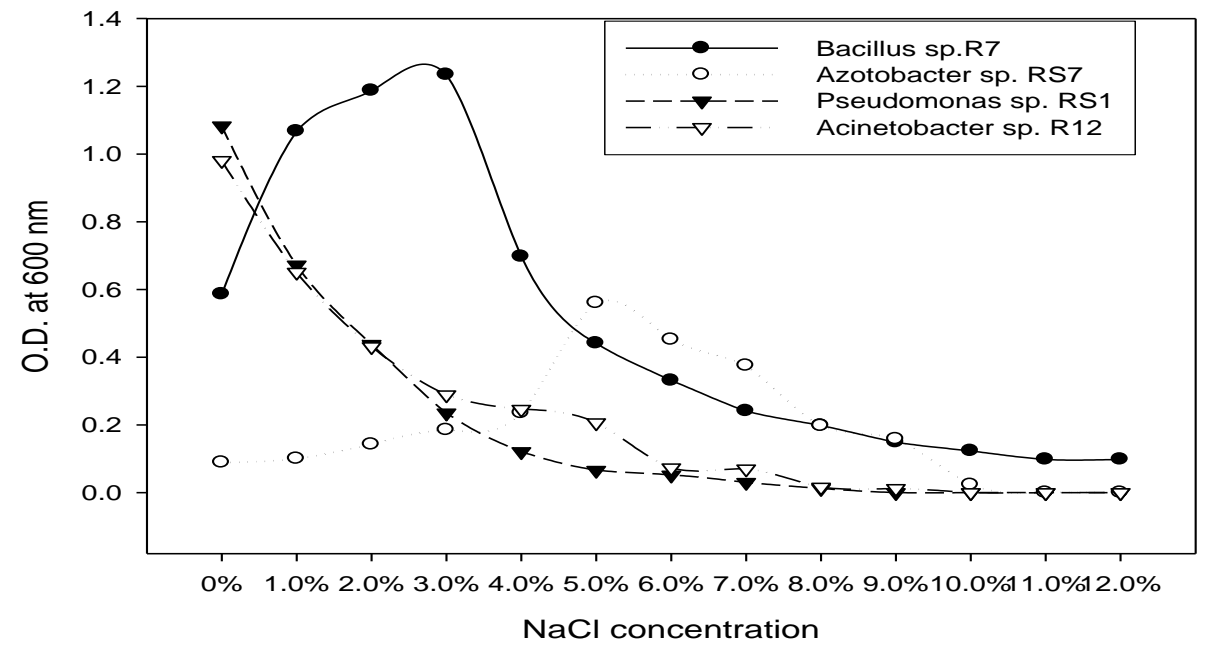

Fig.3 Cluster analysis (Bray Curtis) of selected. Data for analysis based on growth promotions activities of strains as compared to control (Table-4)

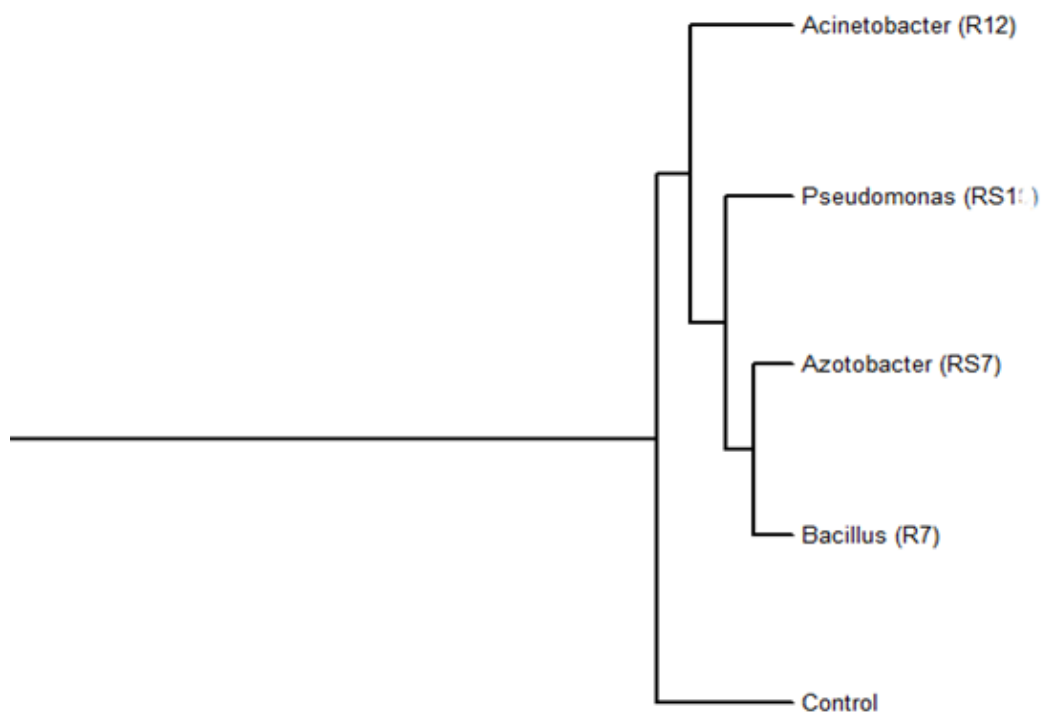


Table.4 Effect of PGPR strains on growth activity of Bitter melon

\begin{tabular}{|c|c|c|c|c|c|c|}
\hline $\begin{array}{l}\text { Plant with } \\
\text { Bacteria } \\
\text { inoculation }\end{array}$ & $\begin{array}{l}\text { Percent of seed } \\
\text { germination } \pm \\
\text { SE }\end{array}$ & $\begin{array}{l}\text { Seedling } \\
\text { length at } \\
\text { 15DAS } \\
(\mathrm{cm})+\mathrm{SE}\end{array}$ & $\begin{array}{l}\text { Plant } \\
\text { length at } \\
60 \text { DAS } \\
(\mathrm{cm})+\text { SE }\end{array}$ & $\begin{array}{l}\text { Fruit Number } \\
\text { per plant } \\
90 \text { DAS } \pm \text { SE }\end{array}$ & $\begin{array}{l}\text { Fruit size } \\
(\mathrm{cm}) \pm \mathrm{SE}\end{array}$ & $\begin{array}{l}\text { Seed Number } \\
\text { per fruit } \pm \\
\text { SE }\end{array}$ \\
\hline Control & $84.9 \pm 4.97$ & $8.83 \pm 1.01$ & $\begin{array}{l}109.93 \pm \\
8.33\end{array}$ & $14 \pm 1.15$ & $9.83 \pm 0.44$ & $8 \pm 1.15$ \\
\hline Bacillus sp. (R7) & $89.9 \pm 0.00$ & $8.84 \pm 1.09$ & $\begin{array}{l}143.4 \pm \\
10.36\end{array}$ & $16.33 \pm 0.88$ & $10.00 \pm 0.29$ & $10 \pm 0.58$ \\
\hline $\begin{array}{l}\text { Azotobacter sp. } \\
\text { (RS7) }\end{array}$ & $100 \pm 0.00$ & $\begin{array}{l}9.50 \pm 1.04 \\
S E\end{array}$ & $\begin{array}{l}142.20 \pm \\
2.35\end{array}$ & $15 \pm 1.20$ & $10.33 \pm 0.33$ & $11 \pm 0.00$ \\
\hline $\begin{array}{l}\text { Pseudomonas sp. } \\
\text { (RS1) }\end{array}$ & $100 \pm 0.00$ & $12.67 \pm 0.88$ & $\begin{array}{l}158.83 \pm \\
5.8\end{array}$ & $18 \pm 1.73$ & $12 \pm 0.58$ & $16 \pm 0.58$ \\
\hline $\begin{array}{l}\text { Acinetobacter sp. } \\
\text { (R12) }\end{array}$ & $75 \pm 8.33$ & $9.33 \pm 1.86$ & $\begin{array}{l}135.10 \pm \\
6.89\end{array}$ & $15.87 \pm 0.58$ & $9.67 \pm 0.33$ & $8 \pm 1.15$ \\
\hline
\end{tabular}

Antibiotic production is an important biocontrol trait of PGPR. Pseudomonas showed maximum antimicrobial activity in human pathogenic strain with Escherichia coli, followed by Pseudomonas aeruginosa and in decreasing order by Bacillus, Azotobacter and least by Acinetobacter. It is earlier reported trait for rhizobacteria with potential for biological control in pseudomonad (Kremmer and Kennedy, 1996). Although we have not characterized the exact chemical nature of active ingredient (s) but it is noteworthy that all the four bacteria possess antimicrobial activity similar to antibiotics.

PGPR strains are able to tolerate and survive the stress condition and alleviate the salinity stress when inoculated in salt stressed plant (Saharan and Nehra, 2011). The lower salt stress enhanced the Bacillus (R7) growth almost double and the strain tolerated maximum salt stress compared to other strains. The tolerance of salt stress in the various PGPR was strain specific property of bacteria. Our findings suggest that salt tolerance is associated with PGPR strains whether it can be taken as PGP trait for PGPR needs extensive investigations. Inoculation of bitter melon seed with selected PGPR isolates such as Bacillus (R7), Azotobacter(RS7),
Pseudomonas (SR10) and Acinetobacter(R12) enhanced plant growth by enhancing the percent of seed germination, seedling length, plant length, fruit per plant, fruit size and the seed number per fruit in comparison to control. Pseudomonas isolates had maximum PGP potential followed by Azotobacter, Bacillus and Acinetobacter. There were a huge number of evidences in support of the study that PGPR strains enhance the growth, seed emergence, crop yield (Kloepper et al., 2004; Herman et al., 2008 and Minorsky, 2008). In addition to high percent of seed germination, seedling and plant growth was also high which was contributed by Phosphate solubilisation and IAA production by the isolates. These results suggested that the increase growth of bitter melon plant by PGPR isolates such as Bacillus (R7), Azotobacter (RS7), Pseudomonas (Rs10) and Acinetobacter (R12) is probably due to multiple mechanisms and the best performance of Pseudomonas (Rs1) on growth and plant vigour of bitter melon is due to high activity of PGP traits as compared to other PGPR isolates. Cluster analysis based PGP traits of PGPR strains revealed that Bacillus (R7) and Azotobacter (RS7) is similar as they formed one cluster and Pseudomonas (Rs10) and Acinetobacter (R12) formed separate clusters as later have 
maximum and minimum activities of PGP and their effect on bitter melon.

\section{Acknowledgement}

Authors are thankful to Head, Department of Botany for the basic laboratory facilities. The financial support to Ritu Singh in form of UGC Research fellowship from B.H.U thankfully acknowledged.

Abbreviations- PGPR- Plant growth promoting Rhizobacteria; PGP- Plant Growth promotion; DRMOs- Deleterious rhizospheric microorganisms; NBRIP- National Botanical Research Institute's Phosphate; IAA- Indole Acetic acid.

\section{References}

Bergey's Manual of Determinative Bacteriology $9^{\text {th }}$, 1994. Eds. Sneath PHA, Staley JT, Williams ST. Williams and Wikkins, Baltimore, USA.

Bergey's Manual of Determinative Bacteriology, 1984. Eds. Williams ST, Sharpe ME, Holt GJ. Williams and Wikkins, Baltimore, USA.

Boddey, R.M., Dobereiner, J. 1995. Nitrogen fixation associated with grasses and cereals: recent progress and perspectives for the future. Fert. Res., 42: 241-250.

Brick, J.M., Bostock, R.M., Silverstone, S.E. 1991. Rapid in situ assay for indole acetic acid production by bacteria immobilized on nitrocellulose membrane. Appl. Environ. Microbiol., 57: 535-538.

Cappuccino, J.G., Sherman, N. 1992. Biochemical activities of microorganisms. In: Microbiology, A Laboratory Manual. The Benjamin / Cummings Publishing Co. California, USA.
Carlton, B.C., Brown, B.J. 1981. General characterization. In Manual of Methods for General Microbiology, pp 409-443. Edited by Gerhardt P, Murray RGE, Costilow RN, Nester EW, Wood WA, Krieg NR and Phillips GH. Washington, DC: American Society for Microbiology.

Cassán, F., García Salamone, I. 2008. Azospirillum sp. cell physiology, plant response, agronomic and environmental research in Argentina. BuenosAires: Asociacion Argentina de Microbiologia.

Castric, P.A. 1975. Hydrogen cyanide, a secondary metabolite of Pseudomonas aeruginosa. Can. J. Microbiol., 21: 613618.

Cattelan, A.J., Hartel, P.G., Fuhrmann, J.J. 1999. Screening of plant growth promoting rhizobacteria to promote early soybean growth. Soil Sci. Soc. Am. J., 63: 1670-1680.

De Vleeschauwer, D., Höfte, M. 2007. Using Serratia plymuthica to control fungal pathogens of plants. $C A B$ Rev., 2: 46.

Dey, R., Pal, K.K., Bhatt, D.M., Chauhan, S.M. 2004. Growth promotion and yield enhancement of peanut (Arachis hypogaea L.) by application of plant growth- promoting rhizobacteria. Microbial Res., 159: 371-394.

Gonzalez- Lopez, J., Salmeron, V., MartinezToledo, M.V., Ballesteros, F. 1986. Production of Auxins, Gibberellins and cytokinins by Azotobacter vinlandii ATCC 12837 in chemically defined media and dialyzed soil media. Soil Biol. Biochem., 18: 119- 120.

Glick, B.R. 1995. The enhancement of plant growth by free-living bacteria. Can. J. Microbiol., 41: 109-117.

Gupta, R.S., Rekha, S., Aparna, Kuhad, R.C. 1994. A modified plate assay for screening phosphate solubilising microorganisms. J. Gen. Appl. Microbiol., 40: 255-260. 
Herman, M.A.B., Nault, B.A., Smart, C.D. 2008. Effect of plant growth promoting rhizobacteria on bell pepper production and green peach aphid infestations in New York. Crop. Protect., 27: 9961002.

Jackson, M.L. 1967. Soil chemical analysis, Prentice Hall of India Pvt. Ltd., New Delhi. 183-192.

Jackson, M.L. 1973. Estimation of phosphorus content. Soil chemical analysis, Printer Hall, New Delhi (India.

Jacobsen, B.J., Zidack, N.K., Larson, B.J. 2004. The role of Bacillus-based biological control agents in integrated pest management systems: plant diseases. Phytopathol., 94: 1272-1275.

Joseph, B., Patra, R.R., Lawrence, R. 2007. Characterization of plant growth promoting Rhizobacteria associated with chickpea (Cicer arietinum L). Int. J. Plant Prod., 1: 141-152.

King, E.O., Ward, M.K., Randey, D.E. 1954. Two simple media for the demonstration of pyocyanin and fluorescein. J. Lab. Clinic. Med., 44: 301-307.

Kloepper, J.W., Ryu, C.M., Zhang, S. 2004. Induced systematic resistance and promotion of plant growth by Bacillus spp. Phytopathol., 94: 1259- 1266.

Kremmer, R.J., Kennedy, A.S. 1996. Rhizobacteria as biocontrol agents of weeds. Weed Technol. 10 (Supp9): 1768- 1774

Kumar, A., Kumar, A., Devi, S., Patil, S. 2012. Isolation, screening and characterization of bacteria from rhizospheric soil for different plant growth promotion (PGP) activities: an in vitro study. Recent Res. Sci. Technol., 4(1): 01- 05.

Long, S.R. 2001. Gene and signals in the Rhizobium-legume symbiosis. Plant Physiol., 125: 69-72.
Loper, J.E., Scroth, M.N. 1986. Influence of bacterial sources on indole-3 acetic acid on root elongation of sugarbeet. Phytopathol., 76: 386-389.

Loper, J.E., Kobayashi, D.Y., Paulsen, I.T. 2007. The genomic sequence of Pseudomonas fluorescens Pf-5: insights into biological control. Phytopathol., 97: 233-238.

Lucy, M., Reed, E., Glick, B.R. 2004. Applications of free living plant growth-promoting rhizobacteria. Review Antonie Van Leeuwenhoek. 86: $1-25$.

Maier, R.M., Pepper, I.L., Gerba, C.P. 2009. Environmental Microbiology $2^{\text {nd }}$ (ed. Academic Press, London.

Mehmood, Z., Ahmad, I., Mohammad, F., Ahmad, S. 1999. Indian medicinal plants: A potential source of anticandidal drugs. Pharma. Biol., 37: 237-242.

Minorsky, P.V. 2008. On the inside. J. Plant Physiol., 146: 323- 324.

Mirza, M.S., Ahmad, W., Latif, F., Haurat, J. 2001. Isolation, partial characterization, and the effect of plant growthpromoting bacteria (PGPB) on micropropagated sugarcane in vitro. Plant Soil., 237: 47-54.

Morgan, J.A., Bending, G.D., White, P.J. 2005. Biological costs and benefits to plant-microbe interactions in the rhizosphere. J. Exp. Bot., 56: 17291739.

Nautiyal, C.S., Mehta, S. 2001. An Eficient Method for Qualitative Screening of Phosphate- Solubilizing bacteria. Microbiol., 43: 51- 56.

Norris, J.R., Chapman, H.M. 1968. Classification of Azotobacter. In: Identification methods for microbiologists Gibbs B.M. and Shapton D.A. Eds.) Academic press, London and New York. pp 19-27. 
Probanza, A., Lucas Garcia, J.A., Ruiz Palomino, M., Ramos, B. 2002. Pinus pinea $\mathrm{L}$. seedling growth and bacterial rhizosphere structure after inoculation with PGPR Bacillus (B. licheniformis CECT 5106 and B.pumilus CECT 5105. Appl. Soil Ecol., 20: 75-84.

Reyes, V.A., Valduz, Z. 2006. Phosphate solubilising microorganisms isolated from the rhizospheric and bulk soils of colonizer plants at an abandoned rock phosphate mine. Plant Soil, 287: 69-75.

Ryan, R.P., Monchy, S., Cardinale, M., Taghavi, S. 2009. The versatility and adaptation of bacteria from the genus Stenotrophomonas. Nat. Rev. Microbiol., 7: 514-525.

Saharan, B.S., Nehra, V. 2011. Plant Growth Promoting Rhizobacteria: A Critical Review. Life Sci. Med. Res., 21.

Schrey, S.D., Tarkka, M.T. 2008. Friends and foes: streptomycetes as modulators of plant disease and symbiosis. Antonie Van Leeuwenhoek. 94: 11-19.

Schollhorn, R., Burris, R. H. 1967. Acetylene as a competitive inhibitor of $\mathrm{N}$, fixation. Proceedings of the National Academy of Sciences of the United States of America, 58: 213.

Schwyn, B., Neilands, J.B. 1987. Universal chemical assay for detection and determination of siderophore. Anal. Biochem., 160: 47-56.

Vance, E.D., Brookes, P.C., Jenkinson, D.S. 1987. An extraction method for measuring soil microbial biomass. Soil Biol. Biochem., 19: 703-707.

Vessey, J.K. 2003. Plant growth promoting rhizobacteria as biofertlizers. Plant Soil, 255: 571-586.

Xie, H., Pasternak, J.J., Glick, B.R. 1996. Isolation and characterization of mutants of plant growth promoting rhizobacterium Pseudomonas putida GR 12-2 that over produce indoleacetic acid. Curr. Microbiol., 32: 67-71.

Wu, S.C., Cao, Z.H., Li, Z.G., Cheung, K.C. 2005. Effects of biofertilizer containing $\mathrm{N}$-fixer, $\mathrm{P}$ and $\mathrm{K}$ solubilizers and $\mathrm{AM}$ fungi on maize growth: A greenhouse trial. Geoderma, 125: 155-166.

Zhender, G.W., Yao, C., Murphy, J.F., Sikora, E.R. 1999. Microbe-induced resistance against pathogens and herbivores: evidence of effectiveness in agriculture. In: Agarwal AA, Tuzun S, Bent E (eds.), Induced Plant Defences' Against Pathogens and Herbivores: Biochemistry, Ecology and Agriculture. APS Press, St Paul, MN, p. 33.

\section{How to cite this article:}

Ritu Singh, Ajay Kumar, Monika Singh and Kapil D. Pandey. 2017. PGPR Isolates from the Rhizosphere of Vegetable Crop Momordica charantia: Characterization and Application as Biofertilizer. Int.J.Curr.Microbiol.App.Sci. 6(3): 1789-1802. doi: https://doi.org/10.20546/ijcmas.2017.603.205 